\title{
High Incidence of Triple-Negative Tumors in Sub-Saharan Africa: A Prospective Study of Breast Cancer Characteristics and Risk Factors in Malian Women Seen in a Bamako University Hospital
}

\author{
Madani Ly ${ }^{a, c} \quad$ Martine Antoine $^{d} \quad$ Abdoul Karim Dembélé $^{a}$ \\ Pierre Levy ${ }^{\mathrm{e}}$ Anita Rodenas ${ }^{d} \quad$ Boubacari Ali Touréa ${ }^{\mathrm{a}}$ Youssouf Badiaga ${ }^{a}$

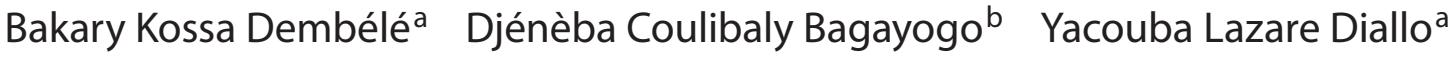 \\ Abdramane A. Konéa Patrice Callard ${ }^{d}$ Jean-François Bernaudin ${ }^{c}$ \\ Dapa Aly Dialloa, b

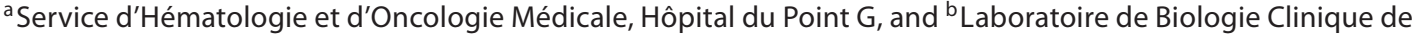
la Faculté de Médecine de Pharmacie et d'Odontostomatologie de Bamako, Bamako, Mali; 'Histologie Biologie Tumorale, and d Anatomie Pathologique, ER2 UPMC Université Paris 6, Hôpital Tenon, and 'Unité de Santé Publique et Statistiques Hôpital Tenon, Paris, France
\end{abstract}

\section{Key Words}

Woman • Breast cancer • Triple-negative tumor • Mali •

Sub-Saharan Africa $\cdot$ Risk factors

\begin{abstract}
Objective: Few studies have been conducted on breast cancer in Sub-Saharan Africa and their results have been suspected to be impaired by artefacts. This prospective study was designed to determine tumor and patient characteristics in Mali with control of each methodological step. These data are necessary to define breast cancer treatment guidelines in this country. Methods: Clinical and tumor characteristics and known risk factors were obtained in a consecutive series of 114 patients. Each technical step for the determination of tumor characteristics [histology, TNM, grade, estrogen (ER) and progesterone receptors (PR), HER2, and Ki67] was controlled. Results: Patients had a mean age of 46 years. Most tumors were invasive ductal carcinomas (94\%), T3-T4 (90\%) with positive nodes (91\%), grade III (78\%), and ER (61\%) and PR (72\%) negative. HER2 was overexpressed in $18 \%$ of
\end{abstract}

cases. The triple-negative subgroup represented $46 \%$, displaying a particularly aggressive pattern ( $90 \%$ grade III; $88 \%$ Ki67 >20\%). Conclusion: This study demonstrates the high incidence of aggressive triple-negative tumors in Mali. Apart from a higher prevalence of premenopausal women, no significant difference in risk factors was observed between triple-negative tumors and other tumors. The hormonal therapy systematically prescribed therefore needs to be revised in light of this study.

Copyright $\odot 2012$ S. Karger AG, Basel

\section{Background}

According to demographic projections, Africa will face an unprecedented growth of cancer burden in the next decades [1]. In this context, there is evidence to suggest an emerging epidemic of breast cancer in Sub-Saharan Africa which already constitutes a major health issue $[1,2]$. Breast cancer is the second leading cancer after cervical cancer and is the leading cancer in Nigerian women

\section{KARGER}

Fax +4161306 1234

E-Mail karger@karger.ch

www.karger.com (c) 2012 S. Karger AG, Basel

$0030-2414 / 12 / 0835-0257 \$ 38.00 / 0$

Accessible online at:

www.karger.com/ocl
Dr. Madani Ly

Service d'Hématologie et d'Oncologie Médicale, Hôpital du Point G

Bamako 333 (Mali)

Tel. +22320225002

E-Mail madanily@sante.gov.ml 
$[3,4]$. The age-specific breast cancer incidence rate has been evaluated to be between 20 and 25 per 100,000 in West African women and it has been estimated that almost 44,000 women die each year from breast cancer in Sub-Saharan Africa [5, 6]. Although the incidence is lower than in developed countries, a significant increase in breast cancer is expected in African countries as a result of urbanization, with changing patterns of risks factors and increasing life expectancy $[1,2]$.

Compared to developed countries, few studies have been conducted on the patient and biological characteristics of breast cancer in Sub-Saharan Africa and no data are currently available in Mali, a country with a population of 14.5 million [7], apart from a previously published retrospective study [8]. The few published epidemiologic studies have suggested that breast cancer exhibits specific features in this region of the world compared to the USA and Europe [9-12], as breast cancer in African women is reported to usually occur at a younger age and to present more aggressive features, such as high-grade tumors, estrogen receptor (ER)-negative and/or triple-negative phenotypes [ER-/progesterone receptor (PR)-/human epidermal growth factor receptor 2 (HER2)-] [1316]. However, the high frequency of ER-negative or triple-negative tumors in Africa has recently been questioned [2], as data derived from some studies have been considered to be possibly related to technical artefacts and more systematic studies have provided contradictory results [2]. Processing of pathological samples is often inadequate due to a lack of resources, with no access to immunohistochemistry, and most studies are retrospective with possibly unsatisfactory storage conditions [17].

For all of these reasons, we decided to set up a prospective study on breast cancer in patients referred to the Department of Medical Oncology and Hematology of the Hôpital du Point G of Bamako, Mali. The primary objective was to determine the tumor characteristics with control of each methodological step from biopsy to immunohistochemistry and fluorescent in situ hybridization (FISH) studies. The secondary objective was to investigate the association of tumor patterns with various risk factors, such as age, BMI, age of menarche, number of pregnancies, and breast-feeding.

\section{Patients and Methods}

\section{Patients and Tumor Sampling}

This study included a prospective consecutive series of 114 patients referred between October 2008 and March 2011 for breast cancer treatment to the Department of Medical Oncology and
Hematology of the Hôpital du Point G university hospital in Bamako. For each patient, the systematic work-up included family history of breast cancer, parity, age at menarche, age at first fullterm birth and duration of breast-feeding, use of hormonal contraceptives, height and weight, and evaluation of BMI. Breast and axillary nodes were systematically evaluated by clinical examination, mammography, and ultrasonography (US). Usual blood tests, chest and bone X-rays, liver US, and, when necessary, chest or liver computerized tomography (CT) were routinely performed. Finally, TNM classification and staging were assessed. Patients were reviewed every 3 months for the first year and every 6 months thereafter, but their results will not be reported or discussed in this study, which is primarily designed to evaluate tumor characteristics at the time of diagnosis.

Core biopsies were performed under $1 \%$ xylocaine local anesthesia, without US guidance for tumors $>1 \mathrm{~cm}$, by physicians after a training period using a Bard $^{\circledR}$ Magnum $^{\circledR}$ device with $14 \mathrm{G}, 16 \mathrm{G}$, or 18G biopsy needles (Bard MC 1410 and MC 1416; Voisins-leBretonneux, France). Four biopsies were taken from each patient, smears were performed for cy tological examination, two biopsies were fixed in $10 \%$ formalin to be paraffin embedded, and two others were frozen and stored at $-80^{\circ} \mathrm{C}$. Paraffin-embedded tissue samples were sent twice a month to the Hôpital Tenon Pathology Department in Paris, France (Prof. P. Callard and Prof. I. Brocheriou) for histological examination and immunohistochemistry. Tumors were classified according to the WHO classification of breast tumors and graded with the Elston and Ellis histoprognostic grade (EE) [18].

The study was approved by the Institutional Ethics Committee of the Faculty of Medicine and Dentistry of Bamako, University of Bamako, Mali (No. 0887/FMPOS), and an informed consent form was signed by all patients.

\section{Immunohistochemistry}

A similar process was performed for all primary antibodies used. Paraffin-embedded specimens were cut into 3 - $\mu \mathrm{m}$ sections, and slides were deparaffinized in xylene for $30 \mathrm{~min}$ and then rehydrated in graded alcohols. Antigen unmasking was obtained by 30 min of incubation in a pH 6 citrate buffer (Target Retrieval Solution, reference: S1699; DAKO, Trappes, France) in a $100^{\circ} \mathrm{C}$ waterbath. After cooling to room temperature, immunohistochemical assays were performed using a NexES ${ }^{\circledR}$ (Roche Ventana ${ }^{\circledR}$, Illkirch, France) immunostainer for $30 \mathrm{~min}$ of incubation at $37^{\circ} \mathrm{C}$ with antibodies diluted according to the manufacturer's recommendations (table 1). Slides were subsequently incubated with an I View ${ }^{\mathrm{TM}}$ DAB Detection Kit (reference: 760-91; Roche Ventana) containing hydrogen peroxide to block endogenous peroxidase activity, biotinylated secondary antibody, streptavidin peroxidase complex, and chromogen. For ER and PR expression, an amplification step using the Roche Ventana Kit (amplification kit reference: 760-080) was added.

Finally, the sections were counterstained with Harris hematoxylin. Internal positive controls, i.e. nuclear labeling after incubation with anti-ER and/or anti-PR antibodies of epithelial cells from normal nonneoplastic ducts, were checked for each section. Controls for HER2 were sections of referenced positive tumors and negative normal epithelial cells. For Ki67, it has been verified that the percentage of immunolabeled cells was always greater than the percentage of mitotic cells observed on HESstained sections. Immunostainings were also controlled accord- 
ing to the external quality program (AFAQAP; France) [19]. Immunostaining results were scored semiquantitatively based on the percentage of cells labeled after immunohistochemical reaction. ER and PR were considered to be positive when more than $10 \%$ of the nuclei of carcinomatous cells were labeled [20,21]. A proliferative state was concluded when more than $20 \%$ of nuclei were labeled with the Ki67 antibody [22]. A scoring system was used for HER2 immunostaining: a score of 3 when more than $30 \%$ of cells exhibited marked peripheral membranous staining, a score of 2 when moderate peripheral staining was observed in more than $10 \%$ of cells, and a score of 1 or 0 when staining was observed in less than $10 \%$ of cells and/or in the presence of weak staining. Only score 3 was considered to be significant for assessing overexpression. Score 2 specimens were tested by FISH for HER2 amplification [23].

\section{Fluorescent in situ Hybridization}

FISH was performed using a ZytoLightSPEC HER2/CEN17 Dual Color Probe Kit (ZytoVision, Bremerhaven, Germany), which includes two directly labeled DNA probes: a locus-specific probe for the HER2 gene labeled with Zygreen similar to FITC and an alpha satellite probe targeting the centromere region of chromosome 17 (CEP17) labeled with Zorange similar to rhodamine. The assay was performed according to the manufacturer's instructions. Briefly, following deparaffinization, slides were incubated in the pretreatment solution $\left(98^{\circ} \mathrm{C}, 15 \mathrm{~min}\right)$, rinsed, and then digested with pepsin $\left(37^{\circ} \mathrm{C}, 15 \mathrm{~min}\right)$. Slides were rinsed and then dehydrated with graded alcohols and air dried. The ZytoLightSPEC HER2/ CEN17 Dual Color Probe cocktail $(10 \mu \mathrm{l})$ was applied, a coverslip was sealed, and after a 10 -min denaturation step at $75^{\circ} \mathrm{C}$ the specimens were hybridized overnight at $37^{\circ} \mathrm{C}$. Slides were then washed and counterstained with $30 \mu \mathrm{l}$ DAPI/antifading solution for 15 min. The presence of the two probes was evaluated using appropriate band-pass filters on an epifluorescence microscope. Average copy numbers of HER 2 and CEP17 from 100 tumor cell nuclei were counted and the signal ratios were calculated. Specimens with a HER2/CEN17 ratio greater than or equal to 2.2 were considered to be amplified (FISH positive), while those with a HER2/CEN17 ratio of less than 2.2 were considered to be nonamplified (FISH negative) [23]. For specimens that were clearly nonamplified (signal ratio less than 1.8) or clearly amplified (signal ratio greater than 2.2) after assessment of 100 cells, no further counting was performed. For specimens with borderline signal ratios of 1.8-2.2, the correlation with immunohistochemistry was controlled in order to reveal potential heterogeneity, and an additional set of 20 cells was counted and the signal ratio was recalculated.

\section{Statistics}

Statistical analysis was performed to compare the clinical and biological characteristics of patients with triple-negative or hormonal receptor (ER and/or PR)-negative tumors and other tumors, i.e. non-triple-negative or hormonal (ER and/or PR)-positive tumors. Quantitative variables where tested using a Student $t$ test for sample sizes greater than 29 and a Mann-Whitney test for smaller sample sizes. Qualitative variables were tested with a $\chi^{2}$ test or Fisher's exact test (table 4). StatView software (V5.0; SAS Institute) was used. Some parameters were grouped into two classes as follows: $\mathrm{T}$ : $1+2$ and $3+4 ; \mathrm{N}: 0$ and $1+2+3$; stage: $1+$ 2 and $3+4$, and SBR grade: 1 and $2 / 3$. Due to test repetition, the significance level was set at 0.002 .
Table 1. Monoclonal antibodies used for immunohistochemistry

\begin{tabular}{llll}
\hline Antibodies & Clone & Dilution & Manufacturer \\
\hline ER & $6 \mathrm{~F} 11$ & $1 / 50$ & $\begin{array}{l}\text { Novocastra } \\
\text { (NCL-ER 6 F11) }\end{array}$ \\
PR & 16 & $1 / 50$ & $\begin{array}{l}\text { Novocastra } \\
\text { (NCL-PGR312) }\end{array}$ \\
Cerb B2/HER2 & Polyclonal & $1 / 1,000$ & DAKO (A0485) \\
Ki67 & Mib1 & $1 / 150$ & DAKO (M7240) \\
\hline
\end{tabular}

\section{Results}

\section{Patients and Clinical Data}

As shown in table 2, the youngest patient of the series was 25 years old and the oldest patient was 82 years old (mean: 46; median: 45). Most patients (90\%) had a tumor larger than $5 \mathrm{~cm}$ at diagnosis, i.e. cT3-T4 with clinical enlarged axillary lymph nodes (99/111; 89\%), and 49/114 (43\%) patients had metastatic disease at diagnosis (liver: 18, bone: 9 , and lung: 22) (table 3).

As shown in table 2, the mean and median BMI were 25 and 24, respectively (normal between 18.5 and 25). The mean and median ages of menarche were 14.5 and 15 years, respectively. Most women (105/114; 92\%) had already had children (average of 5 children), the mean and median ages of the first pregnancy were 17 and 18 years, respectively, and they usually breastfed their babies for a mean and median duration of 17 and 18 months, respectively. Twelve patients (10.5\%) used oral contraception and $7(6 \%)$ had a family history of breast cancer.

\section{Tumor Characteristics}

The biological characteristics of the tumors are reported in table 3. It should be emphasized that most tumors $(86 / 110 ; 78 \%)$ had a high EE grade 3 , with more than $20 \%$ of Ki67-labeled cell nuclei in $78 / 102$ cases (76\%). ER and PR were expressed on 39 and $29 \%$ of cells, respectively. CerbB2/HER2, considered to be positive for an immunohistochemical score of 3 or 2 or marked amplification of the HER2 gene locus, was observed in 20/113 cases $(18 \%) ; 53 / 114(46 \%)$ of tumors failed to meet any of the above criteria and were considered to be triple negative. When considering the 66 patients aged $\leq 45$ years, 24 tumors $(51.5 \%)$ were triple negative, 4 tumors were $\mathrm{ER}+$ / HER2+ and/or PR+/HER2+ (3.5\%), 14 tumors were ER+/ HER2- and/or PR+/HER2- (12.5\%), and 10 tumors were ER-/PR-/HER2+ (9\%). 
Table 2. Clinical characteristics of the 114 patients

\begin{tabular}{|c|c|c|c|c|c|c|}
\hline \multirow[t]{2}{*}{ Characteristics } & \multirow{2}{*}{$\begin{array}{l}\text { Overall } \\
(\mathrm{n}=114)\end{array}$} & \multirow{2}{*}{$\begin{array}{l}\text { Triple-negative } \\
\text { tumors } \\
(\mathrm{n}=53)\end{array}$} & \multicolumn{4}{|c|}{ Non-triple-negative tumors } \\
\hline & & & $\begin{array}{l}\text { Total } \\
(\mathrm{n}=61)\end{array}$ & $\begin{array}{l}\text { RH+HER- } \\
(\mathrm{n}=33)\end{array}$ & $\begin{array}{l}\text { RH+HER+ } \\
(\mathrm{n}=15)\end{array}$ & $\begin{array}{l}\text { Others }^{\mathrm{a}} \\
(\mathrm{n}=13)\end{array}$ \\
\hline Age, years & $46(25-82)$ & $44.24(28-73)$ & $48.03(25-82)$ & $50.27(25-82)$ & $44.6(28-60)$ & $46.31(25-65)$ \\
\hline Number of patients $<50$ years of age & 74 & 42 & 32 & 16 & 10 & 6 \\
\hline Number of patients $>50$ years of age & 40 & 11 & 29 & 17 & 5 & 7 \\
\hline Height, $\mathrm{cm}$ & $164(142-188)$ & $164.7(154-180)$ & $164.1(142-188)$ & $163.09(146-175)$ & $166.8(145-188)$ & $163.92(142-182)$ \\
\hline BMI & $25(15-40)$ & $24.11(15-39)$ & $25.77(16-40)$ & $25.48(16-39)$ & $26.6(18-40)$ & $25.54(18-33)$ \\
\hline Age of menarche, years & $14.5(10-20)$ & $14.40(10-18)$ & $14.6(13-20)$ & $14.53(13-16)$ & $15.07(13-16)$ & $14.53(13-16)$ \\
\hline Number of full-term pregnancies & $5(1-15)$ & $5.3(0-14)$ & $4.63(0-15)$ & $5(0-12)$ & $3.46(0-7)$ & $5.07(0-15)$ \\
\hline Breast-feeding duration, months & $17(6-36)$ & $17.81(0-36)$ & $16.57(0-24)$ & $16.09(0-24)$ & $16.6(0-24)$ & $17.76(0-24)$ \\
\hline
\end{tabular}

Values are presented as means (range) unless otherwise stated.

a This subgroup included 5 RH-HER2+ tumors and tumors for which immunohistochemistry results were not available for 1 of the 3 markers.

Table 3. Clinical and biological characteristics of tumors

\begin{tabular}{lc}
\hline Characteristics & $\mathrm{n}(\%)$ \\
\hline Age & \\
$\quad<50$ years & $74(68)$ \\
$\quad$ 50 years & $40(35)$ \\
TNM classification & \\
T1-T2 & $12 / 114(11)$ \\
T3 & $11 / 114(10)$ \\
T4 & $91 / 114(80)$ \\
N0 & $10 / 114(9)$ \\
N1 & $43 / 114(38)$ \\
N2 & $38 / 114(33)$ \\
N3 & $23 / 114(20)$ \\
M1 & $49 / 114(43)$ \\
Histology & \\
Invasive ductal carcinoma & $107 / 114(94)$ \\
Other & $6 / 114(6)$ \\
EE grading & \\
Grade 1 & $4 / 110(4)$ \\
Grade 2 & $20 / 110(18)$ \\
Grade 3 & $86 / 110(78)$ \\
Hormonal receptors ${ }^{\mathrm{b}}$ & \\
ER $<10 \%$ & $69 / 113(61)$ \\
ER $\geq 10 \%$ & $44 / 113(39)$ \\
PR <10\% & $81 / 112(72)$ \\
PR $\geq 10 \%$ & $31 / 112(28)$ \\
HER2 expression & \\
HER2 & \\
HER2 positive & $93 / 113(82)$ \\
RH+HER2- & $20 / 113(18)$ \\
RH+HER2+ & $33 / 113(29)$ \\
RH-HER2+ & $15 / 113(13)$ \\
Kriple negative $>20 \%$ & $5 / 113(4)$ \\
\hline & $78 / 102(76)$ \\
\hline
\end{tabular}

a According to Elston and Ellis. ${ }^{b}$ Evaluated by immunohistochemistry. ${ }^{\mathrm{c}}$ Evaluated by immunohistochemistry and/or FISH.

\section{Comparison of Characteristics and Risk Factors}

between Triple-Negative and Non-Triple-Negative

\section{Tumors}

The clinical characteristics and risk factors of patients according to the various subgroups of tumors are shown in table 2 and comparative results are presented in table 4. As indicated in Materials and Methods, the significance level was set at 0.002 due to test repetition. No significant difference was observed between patients with triple-negative tumors and patients with other tumors in terms of height, BMI, age of menarche, number of full-term pregnancies, duration of breast-feeding, and TNM or stage. However, a significant difference was observed for age, as the triple-negative group comprised significantly more patients under the age of 50 years $(p=0.0028)$. Moreover, more patients in the triplenegative group had received oral contraception ( $\mathrm{p}=$ 0.03 ), but this difference was not considered to be significant at the limit of $\mathrm{p} \leq 0.002$. The main significant differences concerned tumor EE grade and Ki67 labeling $(\mathrm{p} \leq 0.0001)$.

\section{Discussion}

This prospective consecutive series of 114 patients with breast cancer with well-documented clinical and biological characteristics is the first series concerning women living in Mali. As already reported for other SubSaharan countries, patients were younger (mean age: 46 years) than European or North American Caucasian patients, among whom breast cancer is mostly observed in older women (e.g. in France, the incidence of breast can- 
Table 4. Statistics comparing clinical and biological characteristics of triple-negative tumors versus other tumors and hormonal receptor-negative tumors versus other tumors

\begin{tabular}{|c|c|c|}
\hline & $\begin{array}{l}\text { Triple-nega- } \\
\text { tive }(\mathrm{n}=53) \\
\text { versus others } \\
(\mathrm{n}=61)\end{array}$ & $\begin{array}{l}\text { Estrogen } \\
\text { receptor-negative } \\
(\mathrm{n}=66) \text { versus } \\
\text { others }(\mathrm{n}=48)\end{array}$ \\
\hline Age $^{\mathrm{a}}$ (years) & $\mathrm{p}=0.102$ & $\mathrm{p}=0.183$ \\
\hline Height $^{\mathrm{a}}(\mathrm{cm})$ & $\mathrm{p}=0.704$ & $\mathrm{p}=0.704$ \\
\hline $\mathrm{BMI}^{\mathrm{a}}$ & $\mathrm{p}=0.137$ & $\mathrm{p}=0.380$ \\
\hline Age of menarche ${ }^{a}$ (years) & $\mathrm{p}=0.181$ & $\mathrm{p}=0.382$ \\
\hline Number of full-term pregnancies ${ }^{\mathrm{b}}$ & $\mathrm{p}=0.185$ & $\mathrm{p}=0.299$ \\
\hline Breast-feeding duration ${ }^{\mathrm{b}}$ (months) & $\mathrm{p}=0.639$ & $\mathrm{p}=0.225$ \\
\hline Oral contraception ${ }^{\mathrm{b}}$ (yes/no) & $\mathrm{p}=0.036$ & $\mathrm{p}=0.055$ \\
\hline $\mathrm{T}^{\mathrm{d}}(1+2 / 3+4)^{\mathrm{c}}$ & $\mathrm{p}=0.796$ & $\mathrm{p}=0.952$ \\
\hline $\mathrm{N}^{\mathrm{d}}(0 / 1+2+3)^{\mathrm{c}}$ & $\mathrm{p}=0.273$ & $\mathrm{p}=0.240$ \\
\hline$M^{c}$ & $\mathrm{p}=0.767$ & $\mathrm{p}=0.648$ \\
\hline Stage $^{\mathrm{d}}(1+2 / 3+4)^{\mathrm{c}}$ & $\mathrm{p}=0.815$ & $\mathrm{p}=0.614$ \\
\hline EE grade $^{\mathrm{d}}(1+2 / 3)^{\mathrm{c}}$ & $\mathrm{p}=0.0024$ & $\mathrm{p}=0.0007$ \\
\hline $\mathrm{Ki} 67^{\mathrm{b}}$ & $\mathrm{p}<0.0001$ & $\mathrm{p}<0.0001$ \\
\hline
\end{tabular}

${ }^{a}$ Student's t test. ${ }^{b}$ Mann-Whitney test. ${ }^{c} \chi^{2}$ test. ${ }^{d}$ Two classes were determined for these parameters, as indicated.

cer in women over 50 years is nearly 3 times that observed in women 30-49 years) [24]. Sixty-eight percent of patients from our series were younger than 50 years but, as already emphasized, this finding is probably mainly due to the lower life expectancy in Mali (54.3 years for women, as in most Sub-Saharan African countries, compared to 84.4 years for women in France) [2, 25]. It has been stressed that, due to the low median age of the African population, breast cancer among young women represents a higher proportion of the cases observed in African clinics compared to breast cancer in older women $[2,26]$. However, African-American women are also more likely to be diagnosed with breast cancer at a younger age than are white American women [27]. Various explanations for this higher incidence in young women have been proposed, such as socioeconomic differences, but, as quoted by Akarolo-Anthony et al. [2], a 65-year-old urban woman from Kampala Uganda has only a $20 \%$ lower risk of developing breast cancer than an age-matched European woman. Breast cancer prevalence in younger women in Mali, as in other Sub-Saharan African countries, is therefore very likely at least partly due to demographic characteristics. This aspect highlights the need for cancer registries to record the age-adjusted prevalence and incidence of breast cancer.

Triple-Negative Breast Cancer in Mali
Breast cancer biology in African women, particularly their hormonal receptor status, is a controversial issue. Several studies have reported that African breast cancers are mostly hormone receptor poor [13-16]. However, it has been rightly suggested that this observation could be due to artefacts related to the problems encountered by pathologists in low-income countries $[2,17]$. We therefore decided to set up this prospective study with control of each technical step, and all immunohistochemical and FISH studies were performed in the Pathology Department of a French university hospital (Hôpital Tenon, APHP, Paris), a breast cancer pathology reference center. Moreover, nonneoplastic duct cells on the same section expressing endocrine receptors were used as internal controls. In this context, we found that $46 \%$ of tumors could be classified as 'triple negative' and 58\% were considered to be hormone receptor poor. In Caucasian patients, triple-negative or basal-like tumors account for $16 \%$ of all breast cancers [27], while in our study $46.5 \%$ of tumors were triple negative. This result supports the finding that breast cancer in African woman, and Malian women in the present study, mostly corresponds to hormone receptor-poor tumors. This result is in agreement with data obtained from other African countries. We recently reviewed various studies of breast cancer in African women, most of which reported $40-55 \%$ of triplenegative tumors [28]. A high frequency of triple-negative tumors has also been reported in African-American patients. A recent study in premenopausal women shown that the prevalence of triple-negative breast cancer in African-American and white American women was 39 and $16 \%$, respectively [27]. Although a potential risk associated with African ancestry is still under debate, the triplenegative burden in African-American women cannot be explained exclusively by socioeconomic factors [29].

A large number of live births and a younger age at the first full-term pregnancy, as in this series, is usually considered to lower the risk of breast cancer in Western countries. However, Millikan et al. [30] reported that women between 20 and 72 years of age have an increased risk of basal-like tumors, which are triple-negative tumors, associated with these conditions. Various factors have been suggested to be risk factors for triple-negative tumors. In the present series, we therefore compared patients with triple-negative or hormone receptor-poor tumors with other patients. More patients under the age of 50 years presented a triple-negative tumor, which indicates that triple-negative tumors were observed with a higher prevalence in the premenopausal women of our series. Similarly, Carey et al. [27] reported a high prevalence (59\% in 
their series) of basal-like breast cancer (i.e. triple negative) in premenopausal African-American women. In contrast, the present study did not reveal any significant differences for most of the known risk factors (BMI, age at menarche, number of full-term pregnancies, cumulative duration of breast-feeding, or stage of disease) $[29,31,32]$. Analysis of data from 30 countries has clearly shown that, in developed countries, a longer breast-feeding period has a protective effect against breast cancer, i.e. about a 5\% reduction of the relative risk per 12 months of breastfeeding [32]. However, this risk factor was not observed in our study, probably because $92 \%$ of the women in our series, like most Malian women, had already had children and all Malian mothers breast-feed their babies. In contrast, hormonal contraceptive use was more frequent among patients with triple-negative tumors, but this difference was not significant at the limit of $\mathrm{p} \leq 0.002$. This could be due to the small sample size of this series. The relationship between oral contraceptive use and breast cancer risk has been the subject of extensive research. Analysis of a series of 897 breast cancers in patients aged $\leq 45$ years showed a relative risk of 4.2 associated with oral contraceptive use specific for triple-negative tumors in younger patients, but this association was not observed for other breast cancers [29]. The mechanisms by which oral contraceptive use is associated with a high risk of ERnegative breast cancer are still unknown. However, one of them, the promoting role of estrogen on tumors via stromal cells and angiogenesis, has been described [33]. In the specific setting of our study, our results must be considered cautiously and need to be re-evaluated in a larger series taking into account the type of oral contraception, duration, and age of first use.

Comparison of triple-negative or hormone receptorpoor tumors with other tumors of the series did not reveal any significant differences in terms of CTNM or disease stage, but, as reported for this subset of tumors in Europe or the USA, a highly significant relationship was observed with a high histoprognostic grade and a high Ki67 proliferative index. This association between aggressive parameters and triple-negative breast cancer has been described in a large cohort of patients [30]. Triplenegative breast cancer with high Ki67 is associated with more aggressive clinical features and a pattern of early recurrence. These patients therefore require particularly stringent follow-up during the first 3 years after treatment $[22,34,35]$.

The results of this study have an impact on the treatment of breast cancer in Mali and other Sub-Saharan African countries in which hormonal therapy is systemati- cally proposed as the hormonal receptor status is more often not available for treatment decisions. Systematic treatment with tamoxifen is therefore inappropriate for most patients and, in patients with estrogen-independent cancer, could be responsible for harmful side effects such as deep vein thrombosis or osteoporosis with no significant effect on the tumor [36,37]. Treatment options for triple-negative breast cancer are currently limited to cytotoxic chemotherapy, but effective low-cost chemotherapy needs to be developed for low-income countries [38]. Novel targeted therapies for this subset of tumors are also under development [39].

\section{Conclusion}

This prospective study of 114 patients showed that most women with breast cancer managed by physicians and oncologists in Bamako, Mali, are relatively young, with aggressive hormone receptor-poor tumors that require cytotoxic chemotherapy either as adjuvant therapy or as the sole therapy for metastatic patients. In light of this study, the hormonal therapy systematically prescribed to Malian women needs to be revised. Moreover, as already emphasized by Akarolo-Anthony et al. [2], 'hub and spoke regional pathology laboratories with trained technicians' must be urgently developed to ensure good quality immunohistochemical studies in order to determine the hormonal status of each breast cancer.

\section{Acknowledgments}

The authors would like to thank Drs. Sekou B. Koumare, Soumaila Keita, and Moussa Ouattara, from the Department of Surgery, and the MDs and nurses from the Department of Hematology and Oncology, Hôpital du Point G, Bamako, Mali, and Dr. A. Saul for correction of the manuscript.

They are also greatly indebted to the 'Amis Centre des Tumeurs Tenon' (ACTT) patients' association and Roche-Ventana, France, for their support, the Consulat de France (Ambassade de France) in Bamako, EGIDE from the French ministry of foreign affairs, and the Hôpital Tenon, APHP, Paris (France) and Hôpital du Point G, Bamako (Mali) administrations.

\section{Disclosure Statement}

The authors have no conflicts of interest to declare. 


\section{References}

-1 Lingwood RJ, Boyle P, Milburn A, Ngoma T, Arbuthnott J, McCaffrey R, Kerr SH, Kerr DJ: The challenge of cancer control in Africa. Nat Rev Cancer 2008;8:398-403.

$\longrightarrow 2$ Akarolo-Antony SN, Ogundiran TO, Adebamowo CA: Emerging breast cancer epidemic: evidence from Africa. Breast Cancer Res 2010;12(suppl 4):S8.

-3 Adesunkanmi ARK, Lawal OO, Adelusola KA, Durosimi MA: The severity, outcome and challenges of breast cancer in Nigeria. Breast 2006;15:399-409.

4 Anyanwu SNC: Breast cancer in eastern Nigeria: a ten year review. West Afr J Med 2000; 19:120-125.

5 Parkin MD, Sitas F, Chirenje M, Stein L, Abratt R, Wabinga H: Part I: Cancer in indigenous Africans-burden, distribution, and trends. Lancet Oncol 2008;9:683-692.

-6 Ferlay J, Shin HR, Bray F, Forman D, Mathers C, Parkin MD: Estimates of worldwide burden of cancer in 2008: GLOBOCAN 2008. Int J Cancer 2010;127:2893-2917.

7 4ème Recensement général de la population et de l'habitat du Mali - RGPH. 2009. http:// instat.gov.ml/contenu_documentation. aspx?type $=23$.

$\$ 8$ Togo A, Traoré A, Traoré C, Dembélé BT, Kanté L, Diakité I, Maïga A, Traoré SO, Coulibaly AC, Diallo G: Cancer du sein dans deux centres hospitaliers de Bamako (Mali): aspects diagnostiques et thérapeutiques. J African Cancer 2010;2:88-91.

$\checkmark 9$ Fregene A, Newman LA: Breast cancer in Sub-Saharan Africa: how does it relate to breast cancer in African-American women? Cancer 2005; 103:1540-1550.

10 Gukas ID, Jennings BA, Mandong BM, Manasseh AN, Harvey I, Leinster SJ: A comparison of the pattern of occurrence of breast cancer in Nigerian and British women. Breast 2006;15:90-95.

11 Ihekwaba FN: Breast cancer in Nigerian women. Br J Surg 1992;79:771-775.

12 Sarré B, Ogougbémy M, Dotou C, Lopy J, Ndionne P, Frank K, Drave K, Diouf MB: Aspects épidémiologique, thérapeutique et pronostique des cancers du sein: a propos de 473 cas colligés à l'hôpital principal de Dakar. Dakar Med 2006;51:92-96.

$\checkmark 13$ Bird PA, Hill AG, Houssami N: Poor hormone receptor expression in East African breast cancer: evidence of a biologically different disease? Ann Surg Oncol 2008;15: 1983-1987.

-14 Yarney J, Vanderpuye V, Clegg Lamptey JN: Hormone receptor and HER-2 expression in breast cancers among Sub-Saharan African women. Breast J 2008;14:510-511.

-15 Huo D, Ikpatt F, Khramtsov A, Dangou JM, Nanda R, Dignam J, Zhang B, Grushko T, Zhang C, Oluwasola O, Malaka D, Malami S, Odetunde A, Adeoye AO, Iyare F, Falusi A, Perou CM, Olopade OI: Population differences in breast cancer: survey in indigenous African women reveals over-representation of triple-negative breast cancer. J Clin Oncol 2009;27:4515-4521.

16 Adebamowo CA, Famooto A, Ogundiran TO, Aniagwu T, Nkwodimmah C, Akang EE: Immunohistochemical and molecular subtypes of breast cancer in Nigeria. Breast Cancer Res Treat 2008;110:183-188.

-17 Anderson BO, Shyyan R, Eniu A, Smith RA, Yip CH, Bese NS, Chow LW, Masood S, Ramsey SD, Carlson RW: Breast cancer in limited-resource countries: on overview of the Breast Health Global Initiative 2005 guidelines. Breast J 2006;12(suppl 1):3-15.

18 Tavassoli FA, Devilee P (eds): World Health Organization Classification of Tumors: Pathology and Genetics of Tumours of the Breast and Female Genital Organs. Lyon, IARC Press, 2003, pp 9-48.

19 Démarche de qualité en Anatomie et Cytologie Pathologiques (ACP). 2005. http://www. afaqap.org.

20 Harvey JM, Clark GM, Osborne CK, Allred DC: Estrogen receptor status by immunohistochemistry is superior to the ligand-binding assay for predicting response to adjuvant endocrine therapy in breast cancer. J Clin Oncol 1999;17:1474-1481.

21 Regan MM, Viale G, Mastropasqua M G, Maiorano E, Golouh R, Carbone A, Carbone A, Brown B, Suurküla M, Langman G, Mazzucchelli L, Braye S, Grigolato P, Gelber RD, Castiglione-Gertsch M, Price KN, Coates AS, Goldhirsch A, Gusterson B: Re-evaluating adjuvant breast cancer trials: assessing hormone receptor status by immunohistochemical versus extraction assays. J Natl Cancer Inst 2006;98:1571-1581.

2 Bouzubar N, Walker KJ, Griffitths K, Ellis IO, Elston CW, Robertson JF, Blamey RW, Nicholson RI: Ki67 immunostaining in primary breast cancer: pathological and clinical associations. Br J Cancer 1989;59:943-947.

23 Wolff AC, Hammond EH, Schwartz JN, Hagerty KL, Craig Allred D, Cote RJ, Dowsett M, Fitzgibbons PL, Hanna WM, Langer A, McShane LM, Paik S, Pegram MD, Perez EA, Press MF, Rhodes A, Sturgeon C, Taube SE, Tubbs R, Vance GH, Van de Vijver M, Wheeler TM, Hayes DF: American Society of Clinical Oncology/College of American Pathologists guideline recommendations for human epidermal growth factor receptor 2 testing in breast cancer. J Clin Oncol 2007;25:118-145.

24 Allemand H, Seradour B, Weill A, Ricordeau P: Baisse de l'incidence des cancers du sein en 2005 et 2006 en France: un phénomène paradoxal. Bull Cancer 2008;95:11-15.

25 Central Intelligence Agency: Mali in CIA World Fact Book. 2011. https://www.cia.gov.

26 Parkin MD, Ferlay J, Hamdi-cherif M, Sitas F, Thomas JO, Wabinga H, Whelan SL: Cancer in Africa: Epidemiology and Prevention. Lyon, IARC, 2003.

27 Carey LA, Perou CM, Livasy CA, Dressler LG, Cowan D, Conway K, Karaca G, Troester MA, Tse CK, Edmiston S, Deming SL,
Geradts J, Cheang MCU, Nielsen TO, Moorman PG, Earp HS, Millikan RC: Race, breast cancer subtypes, and survival in the Carolina Breast Cancer Study. JAMA 2006;295: 2492-2502.

28 Ly M, Antoine M, André F, Callard P, Bernaudin JF, Diallo DA: Le cancer du sein en Afrique sub-saharienne: état actuel des connaissances. Bull Cancer 2011;98:797-806.

29 Dolle JM, Daling JR, White E, Brinton LA, Doody DR, Porter PL, Malone KE: Risk factors for triple-negative breast cancer in women under the age of 45 years. Cancer Epidemiol Biomarkers Prev 2009;18:1157-1166.

-30 Millikan RC, Newman B, Tse CK, Moorman PG, Conway K, Smith LV, Labbok MH, Geradts J, Bensen JT, Jackson S, Nyante S, Livasy C, Carey L, Earp HS, Perou CM: Epidemiology of basal-like breast cancer. Breast Cancer Res Treat 2008;109:123-139.

- 31 Yang XR, Sherman ME, Rimm DL, Lissowska J, Brinton LA, Peplonska B, Hewitt SM, Anderson WF, Szeszenia-Dabrowska N, BardinMikolajczak A, Zatonski W, Cartun R, Mandich D, Rymkiewicz G, Ligaj M, Lukaszek S, Kordek R, García-Closas M: Differences in risk factors for breast cancer molecular subtypes in a population-based study. Cancer Epidemiol Biomarkers Prev 2007;16:439-443.

32 Collaborative Group on Hormonal Factors in Breast Cancer: Breast cancer and breastfeeding: collaborative reanalysis of individual data from 47 epidemiological studies in 30 countries, including 50,302 women with breast cancer and 96,973 women without the disease. Lancet 2002;360:187-195.

33 Gupta PB, Proia D, Cingoz O, Weremowicz J, Naber SP, Weinberg RA, Kuperwasser C: Systemic stromal effects of estrogen promote the growth of estrogen receptor-negative cancers. Cancer Res 2007;67:2062-2071.

34 Voduc KD, Cheang MC, Tyldesley S, Gelmon $\mathrm{K}$, Nielsen TO, Kennecke H: Breast cancer subtypes and the risk of local and regional relapse. J Clin Oncol 2010;28:1684-1691.

35 Keam B, Im SA, Lee KH, Han SW, Oh DY, Kim JH, Lee SH, Han W, Kim DW, Kim TY, Park IA, Noh DY, Heo DS, Bang YJ: Ki-67 can be used for further classification of triple negative breast cancer into two subtypes with different response and prognosis. Breast Cancer Res 2011;13:R22.

36 Dawson SJ, Provenzano E, Caldas C: Triple negative breast cancers: clinical and prognostic implications. Eur J Cancer 2009;45:27-40.

37 Pal SK, Childs BH, Pegram M: Triple negative breast cancer: unmet medical needs. Breast Cancer Res Treat 2011;125:627-636.

38 Kerr DJ, Midgley R: Can we treat cancer for a dollar a day? Guidelines for low-income countries. N Engl J Med 2010;363:801-803.

- 39 O'Shaughnessy J, Osborne C, Pippen JE, Yoffe M, Patt D, Rocha C, Koo IC, Sherman BM, Bradley C: Iniparib plus chemotherapy in metastatic triple-negative breast cancer. $\mathrm{N}$ Engl J Med 2011;346:205-214. 